\title{
Monitoring the Blood Pressure of the Patients during Normal Station Hospital Stay
}

\author{
Mohamed Shehata* \\ Department of Thoracic Transplantation, University Clinic Essen, Essen Germany
}

Submission: March 12, 2017; Published: April 24, 2017

*Corresponding author: Mohamed Shehata, Department of Thoracic Transplantation, University Clinic Essen, Germany,

Email: mohammed.shehatta1@gmail.com

\section{Introduction}

Significant variations of blood pressure are very important clinical events that can lead to serious cardiovascular events, such as stroke, myocardial ischemia, and heart failure. Accordingly, careful measurement of the blood pressure is very important for the classifying the patients, estimation of the associated risks and guiding of the management. Twenty-four hours ambulatory monitoring of the blood pressure remains the method of choice for the diagnosis and risk prediction [1].

\section{Monitoring of Blood Pressure During Hospital Stay}

While the continuous monitoring of blood pressure is applied during the intensive care unit stay and the acute emergency station stay, the monitoring of the blood pressure during the normal station stay is usually performed through the frequent measurement by the nursing team. This is of great importance in cases with known hypertension/hypotension and or hypertensive crisis, especially if the patient can't feel the changes by herself/himself. With many number of patients in the station, this may create a stressful condition for the nursing team.

\section{Suggested Solution}

Limiting the blood pressure monitoring by the nursing team to the initial 2-3 days of the normal station hospital stay and the initial 2-3 days after the medical control of the blood pressure. For the continuous monitoring of the blood pressure during the normal station hospital stay, self-used blood pressure measuring devices could be available in the station and given to the patients of interest, where the patients could measure their blood pressure themselves at least three times a day (Figure 1) and record the measurements for the control by the doctor during the weekly visits, in addition to informing the medical team at any time the blood pressure exceeds or decreases below the guideline limits.

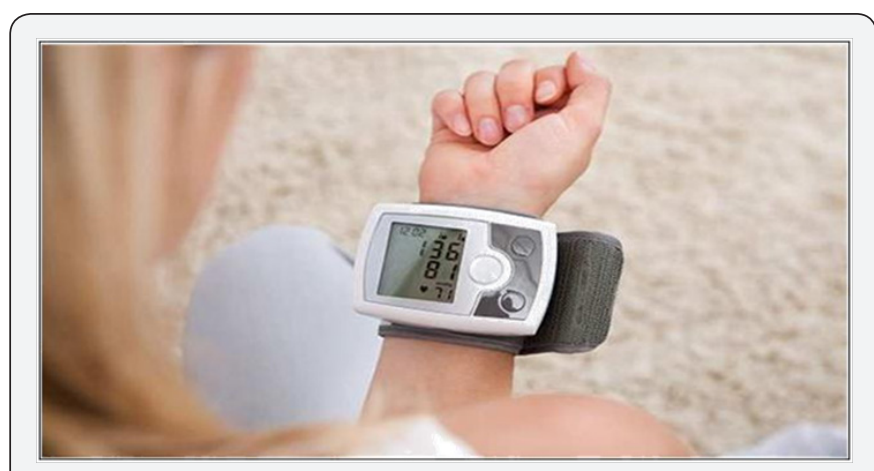

Figure 1: Self measurement of the blood pressure.

The application of this approach might allow the careful monitor of the blood pressure of the patients during the normal station hospital stay, while minimizing the load on the nursing team, especially in situations, where few numbers of nursing personnel is available for relatively many number of patients. However, this approach should be limited to the long term monitor of the already under control blood pressure patients.

\section{References}

1. Pickering TG, Hall JR, Appel LJ, Falkner BE, Graves J, et al. (2005) Recommendations for Blood Pressure Measurement in Humans and Experimental Animals. Part 1: Blood Pressure Measurement in Humans: A Statement for Professionals From the Subcommittee of Professional and Public Education of the American Heart Association Council on High Blood Pressure Research. Circulation 111: 697-716. 
CC (i) This work is licensed under Creative (C) - Commons Attribution 4.0 License
Your next submission with Juniper Publishers will reach you the below assets

- Quality Editorial service

- Swift Peer Review

- Reprints availability

- E-prints Service

- Manuscript Podcast for convenient understanding

- Global attainment for your research

- Manuscript accessibility in different formats

( Pdf, E-pub, Full Text, Audio)

- Unceasing customer service

Track the below URL for one-step submission https://juniperpublishers.com/online-submission.php 